\title{
INFLUENCE OF DIGITAL IMAGES PRELIMINARY NOISING ON STATISTICAL STEGDETECTORS PERFORMANCE
}

Progonov D. O. - PhD, Associate Professor, Associate Professor of the Department of Physics and Information Security Systems, Igor Sikorsky Kyiv Polytechnic Institute, Kyiv, Ukraine.

\begin{abstract}
Context. The problem of sensitive information protection during data transmission in communication systems was considered. The case of reliable detection of stego images formed according to advanced embedding methods was investigated. The object of research is digital images steganalysis of adaptive steganographic methods.

Objective. The goal of the work is performance analysis of statistical stegdetectors for adaptive embedding methods in case of preliminary noising of analyzed image with thermal and shot noises.

Method. The image pre-processing (calibration) method was proposed for improving stego-to-cover ratio for state-of-the-art adaptive embedding methods HUGO, MG and MiPOD. The method is aimed at amplifying negligible changes of cover image caused by message hiding with usage of Gaussian and Poisson noises. The former one is related to influence the thermal noise of chargecoupled device (CCD) based image sensor during data acquisition. The latter one is related to shot noise that originates from stochastic process of electron emission by photons hitting of CCD elements. During the research, parameters of thermal noise were estimated with two-dimensional Wiener filter, while sliding window of size $5 \cdot 5$ pixels was used for parameters evaluation for shot noise.

Results. The dependencies of detection error on cover image payload for advance HUGO, MG and MiPOD embedding methods were obtained. The results were presented for the case of image pre-noising with both Gaussian and Poisson noises, and varying of feature pre-processing methods.

Conclusions. The conducted experiments confirmed effectiveness of proposed approach for image calibration with Poisson noise. Obtained results allow us to recommend linearly transformed features to be used for improving stegdetector performance by natural image processing. The prospects for further research may include investigation usage of special noises, such as fractal noises, for improving stego-to-cover ratio for advanced embedding methods.
\end{abstract}

KEYWORDS: digital image steganalysis, adaptive embedding method, Gaussian noise, Poisson noise.

\author{
ABBREVIATIONS \\ AEM is an adaptive embedding method; \\ CCD is a charge-coupled device; \\ $\mathrm{CI}$ is a cover image; \\ DI is a digital image; \\ EM is an embedding method; \\ IC is an image calibration; \\ $\mathrm{SD}$ is a stegdetector.
}

\section{NOMENCLATURE}

$\beta_{l}$ is the change rate;

$\Delta_{p}$ is a cover image payload;

$\zeta^{2}$ is the deflection coefficient between cover and stego

images distributions;

$\lambda_{L}$ is the Lagrange multiplier;

$\xi$ is a signal whose variance is need to be estimated with a linear model;

$\pi$ is a probability distribution function of selection certain stego image from set of all possible stego images;

$\rho_{i j}(\cdot)$ is a cost function for estimation CI alteration due to individual stego bit hiding into $(\mathrm{i}, \mathrm{j})^{\text {th }}$ pixel of $\mathrm{CI}$;

$\mathrm{Y}$ is the set of all possible stego images;

$\omega, u, v, w$ are weights;

$a$ is the vector of a linear model parameters;

$C($.$) is an image calibration operator;$

$C$ is the set of three-elements cliques for four-pixels adjacency directions;

$D$ is an array of differences between adjacency pixels values;
$D(X, Y)$ is an empirical distortion estimation function;

$E_{\pi}(D)$ is the averaging operator for function $D(X, Y)$ over distribution $\pi$;

$F$ is a feature row vector;

$F_{d n}$ is a denoising filter for image context suppression;

$F_{e}(\cdot)$ is a feature extraction operator from an image;

$G$ is a mixing matrix;

$H$ is the normalized adjacency matrix that is calculated for each type of cliques $C$;

$\mathrm{H}_{4}$ is the ternary entropy function;

$H(\pi)$ is the entropy function;

$\mathfrak{I}$ represents brightness range for 8-bits grayscale image;

$I_{L \cdot L}$ is an identity matrix with size $L \cdot L$ elements;

$k$ is the number of parameters for the SPAM model;

$M$ is a binary message to be embedded;

$M^{a}, M^{b}$ are adjacency matrices for Markov model by scanning grayscale image from left-bottom to right-top and from right-top to left-bottom directions respectively;

$M^{c}, M^{d}$ are adjacency matrices for Markov model by scanning grayscale image from left-top to right-bottom and from right-bottom to left-top directions correspondingly;

$P_{G}^{\perp}$ is the orthogonal projection of residual $r_{l}$ on subspace spanned by left eigenvectors of matrix $G$;

$P_{e}$ is the detection error; 
$P_{F A}$ is the probability of false alarm during detection (assignment cover image as stego one);

$P_{M D}$ is the probability of missed detection (assignment of stego image as cover one);

$r_{l}$ are residuals $r$ inside $p \cdot p$ block surrounding the $l^{\text {th }}$ pixel of CI;

$T$ is a threshold;

$U$ is an unprocessed (non-calibrated) image;

$X$ is a cover image;

$Y$ is a stego image;

$\operatorname{Pr}(a)$ is the probability of event $a$;

$[a]_{I}$ is the Iverson bracket that equals to one if Boolean expression $a$ is true, and zero otherwise;

\|\|$\|$ is the Euclidean norm for scalars, or Frobenius norm for matrices.

\section{INTRODUCTION}

Counteraction to sensitive data leakage is topical task today. This includes data protection during on-device processing as well as transmission in communication systems. More recently, the latter task has been taken special interest due to development of adaptive embedding methods. These methods aimed at sensitive data hiding into transmitted files, such as digital images, by preserving minimal distortion of cover image $[1,2]$.

Reliable detection of formed stego images requires utilization of a priori information about applied distortion minimization techniques. This information may be limited or even absent for modern AEM that negatively impact on stegdetectors performance.

The object of study is methods for detection of stego images formed according to AEM.

The promising approach to detection of stego images formed according to AEM is increasing stego-to-cover ratio by pre-processing (calibration) of analyzed image. Modern methods for image calibration are aimed at estimation of cover image parameters from the stego one. This requires usage of accurate statistical model of CI that may be inappropriate in case of processing natural images that characterize a high level of parameters variability. Therefore, the development of new IC methods is needed.

The subject of study is methods for increasing stegoto-cover ratio to be used in steganalysis of stego images formed according to advanced AEM.

One of possible solution of mentioned task is amplification of CI negligible changes caused by message hiding [3]. Unlike known calibration methods that require CI model, this approach utilizes only a priori information about message hiding into highly textured and noised areas of cover images. Since messages embedding can be represented as adding anisotropic noise to DI [1], we may apply technique of image preliminary noising (prenoising) for accentuation these changes.

Effectiveness of this approach was shown in paper [4] for state-of-the-art S-UNIWARD adaptive embedding method. Nevertheless, the approach performance is still

(C) Progonov D. O., 2021

DOI $10.15588 / 1607-3274-2021-1-18$ unknown for advanced adaptive model-based EM, such as MG and MiPOD.

The purpose of the work is to analyze performance of statistical stegdetectors for advanced AEM in case of preliminary noising of analyzed image.

\section{PROBLEM STATEMENT}

For a given set of pairs $\left(X_{i}, Y_{i}\right)\left(X_{i}, Y_{i}\right) \in \mathfrak{I}^{M \cdot N}$, $i \in[1 ; Q]$ the task of stegdetector training can be presented as the optimization problem $[1,2]$ :

$$
P_{e}=\min _{P_{F A}} \frac{1}{2}\left(P_{F A}+P_{M D}\left(P_{F A}\right)\right)
$$

Solving of (1) is done under constrain of applying to images a predefined IC transformation $C(\cdot)$ : $\mathfrak{I}^{M \cdot N} \rightarrow \mathfrak{I}^{M \cdot N}$.

Selection of calibration transformation $C(\cdot)$ should be done according to known a priori information about used embedding method. Nevertheless, this information is limited or even absent in most cases. Therefore, the choice of appropriate transformation $C(\cdot)$ that allows solving problem (1) in case of limited a priori information about steganographic method remains an open question. The paper focuses on the case when $C(\cdot)$ relates to image pre-noising with thermal (Gaussian) or shot (Poisson) noises that model physical processes during image capturing.

\section{REVIEW OF THE LITERATURE}

Modern steganographic methods for DI are aimed at message hiding in CI by preserving minimal alterations of its perception quality $[1,2]$. This is achieved by negligible changes of cover elements, namely pixels brightness, in textured areas that are hard to model. Proposed statistical models of CI allow reliably detection these changes in case of analysis either a distortion introduced by known embedding methods or DI with low noise level.

For overcoming mentioned issue, image preprocessing approach has been proposed. The IC is aimed at increasing stego-to-cover ratio by utilization of information about features of either CI or used embedding method. The former case relates to original idea of calibration - to obtain a good estimation of cover image parameters from a stego one [3]. The latter case is based on analysis of a priori information about specific distortions introduced to CI during message embedding.

The seminal work of cover image estimation [5] proposed to use message re-embedding into JPEG-images for quantitatively estimation of CI payload. Despite accurate estimation, the work requires a priori knowledge of used EM that may be inappropriate in real cases. Fridrich et al. [3] proposed to provide multi-stage processing of JPEG images to estimate CI parameters - firstly, JPEG decompression, then cropping image by 4 first rows and columns and, finally, JPEG compression with same JPEG quality factor. This approach showed outstanding results for widespread embedding methods, such as StegHide, 
OutGuess etc. Nevertheless, the approach is suitable only for compressed JPEG images.

The effective IC method was proposed for SRM model of cover image [6]. The method is based on image preprocessing with set of high-pass filters for suppression of image context. Effectiveness of proposed model was proved for wide range of modern EM, such as HUGO [7], WOW [8] etc. This became possible due to painstaking selection of enormous set of two-dimensional high-pass filters. Modification of SRM model, namely maxSRMd2 [9], pursued the same idea by adaptation of used filters to reliably detection of state-of-the-art AEM.

The PSRM model [10] and SR-Net [11] are further evolution of SRM model. The former model is based on post-processing of residuals obtained after image filtering - theirs projection on vectors generated from multivariate Gaussian distribution. The latter model is convolutional artificial neural network that allows learning appropriate filters (convolutional kernels) during training on image dataset. It should be noted that these modifications of SRM model are either compute-intensive or requires usage of a priori information about used EM for laborious selection of appropriate high-pass filters.

For overcoming mentioned drawbacks of CI restoration scheme, methods for feature estimation from stego images were proposed [3, 4]. One of these methods is message re-embedding into stego image for amplifying negligible changes of CI caused by data hiding. This makes these changes "accessible" for further analysis with statistical models. The effectiveness of this approach was shown in papers $[4,12]$ for state-of-the-art adaptive embedding methods, such as HUGO and S-UNIWARD.

In spite of considerable improving detection accuracy for medium (10-25\%) and high (more than 25\%) payload of CI [4], message re-embedding approach still needs a priori information about EM for maximization alterations caused by message hiding. Since re-embedding procedure can be represented as introducing additional noise to DI [4], we may apply other types of noises for amplifying negligible changes of CI caused by data hiding.

The well-known types of noises, which are specific for image capturing pipeline [13], are thermal and shot noises. They related to influence of discrete nature of photons (shot noise) and ambient temperature (thermal noise) on parameters of CCD used in cameras/scanners. These noises can be accurately modelled with Gaussian and Poisson distribution [13]. Therefore, the paper is aimed at performance analysis of statistical stegdetectors in case of preliminary noising of stego images formed according to AEM with Gaussian and Poisson noises.

\section{MATERIALS AND METHODS}

The paper focuses on state-of-the art AEM. The feature of these methods is minimization of total cost by message $M \in\{0,1\}^{K}$ hiding into a cover image $X$ [14]:

$$
D(X, Y)=\sum_{i, j} \rho_{i, j}(X, Y) \stackrel{|M|=\text { const }}{\longrightarrow} \min .
$$

Ideally, cost function $\rho(\cdot)$ in $(2)$ can estimate both $\mathrm{CI}$ alteration due to changing of individual pixel, and nonlinear interaction between these changes [14]. The former estimation can be done with widespread statistical models of CI [1]. The latter estimation requires compute-intensive analysis of pixels changes combinations that becomes intractable even for short messages $M$ (about 100 bits) [14]. Therefore, the simplified function $\rho(\cdot)$ that estimate only CI distortions caused by individual stego bit hiding is used in most real cases.

Selection of pixels to be used during message embedding (2) is performed by heuristic rules that assess noise level in a local neighborhood of $(i, j)^{\text {th }}$ pixel [14]. This allows achieving state-of-the-art empirical security of formed stego images while preserving computational effective optimization methods for cost estimation.

The examples of state-of-the-art AEM are HUGO [7], MG [15] and MiPOD [16] methods. Let us consider in more detail these methods. The HUGO method is based on minimization of CI distortion under constrain of message length $|M|=H(\pi)[7]$ :

$$
\begin{gathered}
\min _{\pi} E_{\pi}(D)=\sum_{Y \in \mathrm{Y}} \pi(Y) \cdot D(X, Y), \\
\text { wrt. }|M|=-\sum_{Y \in \mathrm{Y}} \pi(Y) \cdot \log (\pi(Y)) .
\end{gathered}
$$

Filler et al. [7] proposed to numerical solving of eq. (3) by using adjacency matrix $C_{k l}(X)$ for estimation of CI distortions during message hiding:

$$
\begin{gathered}
D(X, Y)=\sum_{c \in C} \sum_{(k, l) \in \mathfrak{I}} \omega_{k, l} H_{(k, l)}^{c}(Y), \\
\forall(k, l) \in \mathfrak{J}: \omega_{k, l}>0 .
\end{gathered}
$$

For instance, matrix $H$ in the case of row-wise image processing and left-to-right pixels scanning can be calculated as [7]:

$$
\begin{gathered}
H_{(k, l)}(X, Y)=(N \cdot(M-2))^{-1} . \\
\cdot \sum_{i, j}\left[\left(\overrightarrow{D_{i, j}}, D_{i, j+1}\right)(Y)=(k, l)\right]_{I}- \\
\left.-\left[\left(D_{i, j}, D_{i, j+1}\right)(X)=(k, l)\right]_{I}\right), \\
\left(D_{i, j}, D_{i, j+1}\right)(X)=(k, l) \Leftrightarrow \\
\Leftrightarrow\left(D_{i, j}(X)=k\right) \wedge\left(D_{i, j+1}(X)=l\right) .
\end{gathered}
$$

Matrix $H$ for other types of cliques $C=C^{\rightarrow} \cup$ $\cup C^{\leftarrow} \cup C^{\uparrow} \cup C^{\downarrow}$ can be calculated in a way similar to eq. (5)-(6) [7].

In contrast to HUGO method, MG and MiPOD embedding methods are aimed at minimization both CI distortion and statistical detectability of formed stego image $[15,16]$. It is achieved by usage of locally-estimated multivariate Gaussian model of CI noises. The model allows deriving the closed-form expression of SD performance 
as well as capturing the non-stationary character of natural images [16].

The CI processing pipeline is similar for both $\mathrm{MG}$ [15] and MiPOD [16] methods. Firstly, image context is suppressed using denoising filter $F_{d n}$ :

$$
r=X-F_{d n}(X) \text {. }
$$

Secondly, the variance $\sigma_{l}^{2}$ of obtained residuals $r$ is measured with linear model:

$$
r_{l}=G a_{l}+\xi, l \in[1 ; M \cdot N]
$$

Sedighi et al. [16] proposed to use Maximum Likelihood estimation of model parameters:

$$
\sigma_{l}^{2}=\left\|P_{G}^{\perp} r_{l}\right\| /\left(p^{2}-q\right), q \in \mathrm{N} .
$$

Here, $P_{G}^{\perp}$ represents the orthogonal projection of residual $r_{l}$ on $\left(p^{2}-q\right)$ dimensional sub-space spanned by left eigenvectors of matrix $G$. Residuals $r_{l}$ are evaluated within $p \cdot p$ block surrounding the $l^{\text {th }}$ pixel of CI.

The simplified estimation of variance $\sigma_{l}^{2}$ is used for MG method [15]:

$$
\sigma_{l}^{2}=\left\|r_{l}-G\left(G^{T} G\right)^{-1} G^{T} r_{l}\right\| /\left(p^{2}-q\right), q \in \mathrm{N} .
$$

Thirdly, embedding changes $\beta_{l}, \quad l \in[1 ; M \cdot N]$ that minimizes deflection coefficient $\zeta^{2}$ is estimated:

$$
\begin{gathered}
\zeta^{2}\left(\beta_{l}\right)=2 \sum_{l=1}^{M \cdot N} \beta_{l}^{2} \sigma_{l}^{-4} \stackrel{\sum_{l=1}^{M \cdot N} H_{4}\left(\beta_{l}\right)=\text { const }}{\longrightarrow} \text { min, } \\
H_{4}(z)=-2 z \log (z)-(1-2 z) \log (1-2 z) .
\end{gathered}
$$

The deflection coefficient $\zeta^{2}(7)$ is used as a measure of divergence between cover and stego images distributions $[15,16]$.

The optimization problem (8) can be solved using Lagrange multiplier method [16]. Then, change rate $\beta_{l}$ and Lagrange multiplier $\lambda_{\mathrm{L}}$ can be determined by numerical solving of next equations:

$$
\beta_{l}^{2} \sigma_{l}^{-4}=\frac{1}{2 \lambda_{L}} \ln \left(\frac{1-2 \beta_{l}}{\beta_{l}}\right), l \in[1 ; M \cdot N] .
$$

Then, estimated $\beta_{l}$ is converted to corresponding cost $\rho_{l}$ of stego bit hiding in $l^{\text {th }}$ pixel of CI:

$$
\rho_{l}=-\ln \left(\beta_{l}-2\right) \text {. }
$$

Finally, a message $M$ is embedded into CI using syndrome-trellis codes with pixel costs determined according to eq. (9).

The locally-estimated multivariate Gaussian model (7) allows accurately measuring local distortions of CI caused by message hiding [16]. This makes possible achieving state-of-the-art empirical security of formed stego images without taking compute-intensive statistical models.
Wide range of DI statistical models was proposed for revealing stego images formed according to AEM, such as SRM [6], PSRM [10]. Feature of these models is image pre-processing stage for increasing stego-to-cover ratio. In most cases, this stage includes image high-pass filtering with enormous set of two-dimensional filters for image context suppression [6]. This approach shown outstanding result for detection of stego images formed according to AEM. Nevertheless, it became possible due to meticulous selection of filters that allows revealing specific alterations of CI for each embedding method. The selection requires a priori information about peculiarity of EM that may by unavailable in real cases. Therefore, the topical task is development of new IC techniques that do not depend on a priori information of embedding process.

For solving mentioned task we proposed to increase stego-to-cover ratio by amplification of negligible changes of CI. It can be achieved by image noising since message hiding is performed with usage of noise components. The paper focuses on the case of DI noising with thermal and shot noises that accompanied image capturing process. These noises can be accurately modeled with Gaussian and Poisson distributions. Therefore, we may substitute pre-processing stage for widespread DI statistical models with noising operation.

Unfortunately, features obtained for modern statistical models of DI are closely related to image high-pass filtering [6]. Therefore, we took SPAM model [17] that allows estimation correlation features of calibrated DI without any additional processing. Let us describe this model in details.

The calculation of SPAM-features starts by computation the difference array $D$ by processing an image in row-wise and column-wise orders. For example, the array $D$ for the case of row-wise processing and left-to-right pixels scanning of grayscale image $U$ with size $M \cdot N$ pixels can be calculated as [17]:

$$
\begin{gathered}
D_{i, j}=U_{i, j}-U_{i, j+1}, \\
U \in \mathfrak{I}^{M \cdot N}, i \in[1 ; M], j \in[1 ; N-1] .
\end{gathered}
$$

The first-order SPAM features $F_{1}$ are used for modeling array $D$ with first-order Markov process [17]. For the considered example, it leads to:

$$
\begin{gathered}
M_{u, v}^{\overrightarrow{ }}=\operatorname{Pr}\left(D_{i, j+1}=u \mid D_{i, j} \overrightarrow{ }=v\right), \\
u, v \in[-T ; T], T \in \mathrm{N} .
\end{gathered}
$$

If probability $\operatorname{Pr}\left(D_{i, j} \overrightarrow{=}\right)$ is equal to zero, then $M_{u, v}=0$ as well.

The second-order SPAM features $F_{2}$ are taken for modeling difference array $D$ with second-order Markov process [17]. Similarly to eq. (10), we obtain: 


$$
\begin{gathered}
M_{u, v, w}=\operatorname{Pr}\left(D_{i, j+2}=u \mid \overrightarrow{D_{i, j+1}}=v, \overrightarrow{D_{i, j}}=w\right), \\
u, v, w \in[-T ; T], T \in \mathrm{N} .
\end{gathered}
$$

Similarly to $F_{1}$ features, $M_{u, v, w}$ is equal to zero if $\operatorname{Pr}\left(\overrightarrow{D_{i, j+1}}=v, \overrightarrow{D_{i, j}}=w\right)=0$.

The features $F_{1}$ and $F_{2}$ for other scanning directions, namely $c \in\{\rightarrow, \leftarrow, \uparrow\}$, can be estimated in the same way to eq. (10)-(11).

For decreasing dimensionality of SPAM-features, the assumption that statistics in natural images are symmetric with respect to mirroring and flipping [17] is used. Thus, we can separately averaging matrices for horizontal, vertical and diagonal directions to form the final features:

$$
\begin{aligned}
& F_{1 \ldots k}=\left(M^{\rightarrow}+M^{\leftarrow}+M^{\uparrow}+M^{\downarrow}\right) / 4, \\
& F_{(k+1) \ldots 2 k}=\left(M^{a}+M^{b}+M^{c}+M^{d}\right) / 4 .
\end{aligned}
$$

Number of parameters for the first-order SPAM model is $k=(2 T+1)^{2}$, while for the second-order one $k=(2 T+1)^{3}$.

Practical application of SPAM-features requires theirs pre-processing before using in a classifier. The modern methods of feature pre-processing for DI steganalysis can be divided into next groups $[3,12]$ :

1. Non-calibrated features - corresponds to the case of feature extraction from unprocessed image:

$$
F_{n c}=F_{e}(U) \text {. }
$$

2. Features of calibrated image - corresponds to features obtained after image noising:

$$
F_{\text {noise }}=F_{e}(C(U)) \text {. }
$$

3. Linearly transformed features of calibrated image correspond to the difference between features of calibrated and unprocessed images:

$$
F_{D F}=F_{\text {noise }}-F_{n c} \text {. }
$$

4. Cartesian calibrated features - corresponds to the case of merging features of unprocessed and calibrated images:

$$
F_{\text {CC }}=\left[F_{n c} ; F_{\text {noise }}\right] \text {. }
$$

Today, non-calibrated features (12) are rarely used due to theirs negligible differences for cover and stego images [1]. On the other hand, Cartesian calibrated features (15) are widely used for improving SD performance since they preserve features for both initial and calibrated images [3]. Linearly transformed features (14) do not get much attention today [12]. Therefore, performance analysis of stegdetector by usage of these features takes special interest.

\section{EXPERIMENTS}

Performance analysis of statistical SD by image noising was performed on ALASKA dataset [18]. The sub-set of 10,000 grayscale images with size 512.512 pixels was pseudo randomly chosen from the dataset. The case of message embedding into $\mathrm{CI}$ with $\mathrm{HUGO}, \mathrm{MG}$ and $\mathrm{Mi}-$ POD methods was considered. The CI payload $\Delta_{p}$ was changed in range $-3 \%, 5 \%, 10 \%, 20 \%, 30 \%, 40 \%, 50 \%$.

The SD includes ensemble classifier with Fisher Linear Discriminant base learner [19] trained with secondorder SPAM model [17] with threshold parameter $T=3$, leading to 686 features.

The stegdetector was tested according to crossvalidation procedure by minimization of detection error $P_{e}$ (1) [19]. The dataset was divided 10 times into training $(50 \%)$ and testing $(50 \%)$ sub-sets during cross-validation for estimation averaged values of $P_{\mathrm{e}}$.

Image noising was performed with usage of Gaussian and Poisson noises. The former noise is related to thermal noise that influence of CCD based image sensor during data acquisition. In most cases, this noise is well modelled with zero mean Gaussian process. The latter noise is related to shot noise that originates from stochastic process of electron emission by photons hitting of CCD elements.

During the analysis, variance of thermal noises was estimated with two-dimensional Wiener filter $[13,20]$. The window size $w_{s}$ was varied in range $-3 \cdot 3,5 \cdot 5,7 \cdot 7$, $9 \cdot 9$, and $11 \cdot 11$ pixels. The estimated variance was used for generation of corresponding zero-mean Gaussian noise. The mean $\lambda$ for Poisson distribution was estimated with sliding window of size $5 \cdot 5$ pixels.

\section{RESULTS}

After performance analysis of statistical SD by image noising with Gaussian and Poisson noises the dependencies of detection error for AEM and features (13)-(15) were plotted. Fig. 1-5 graphically illustrates the averaged detection error as a function of CI payload and size of sliding windows for $F_{\text {noise }}$ (Fig. 1-2), $F_{D F}$ (Fig. 3) and $F_{C C}$ (Fig. 4) features for the case of image Gaussian noising.

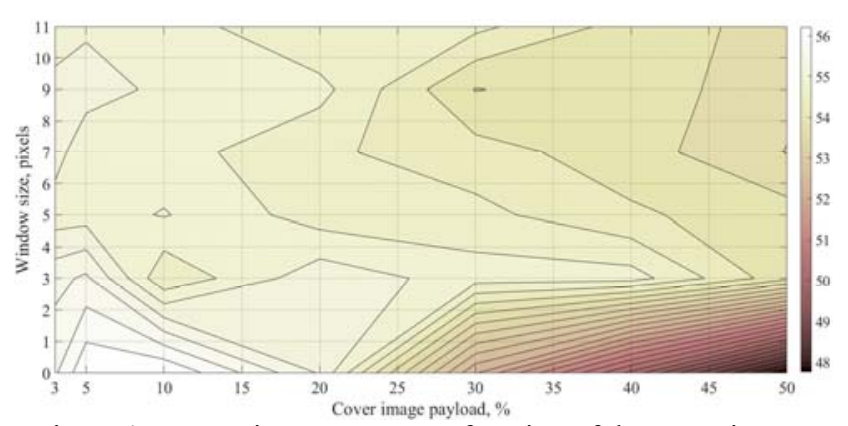

Figure 1 - Detection error $P_{e}$ as a function of the cover image payload and size $w_{s}$ of sliding windows for $F_{\text {noise }}$ features and

Gaussian noising for HUGO method. The $P_{e}$ values for $F_{n \tilde{n}}$ features are represented by $w_{s}=0$ (pixels)

It can be seen from the Fig. 1-2 that images noising with Gaussian noise leads to significant increasing of $P_{\mathrm{e}}$ (about 5\%) for medium $\left(\Delta_{p} \in[10 ; 25]\right)$ and high $\left(\Delta_{p}>25\right)$ payloads of $\mathrm{CI}$ even for small sliding window $\left(w_{s}=3\right)$. 

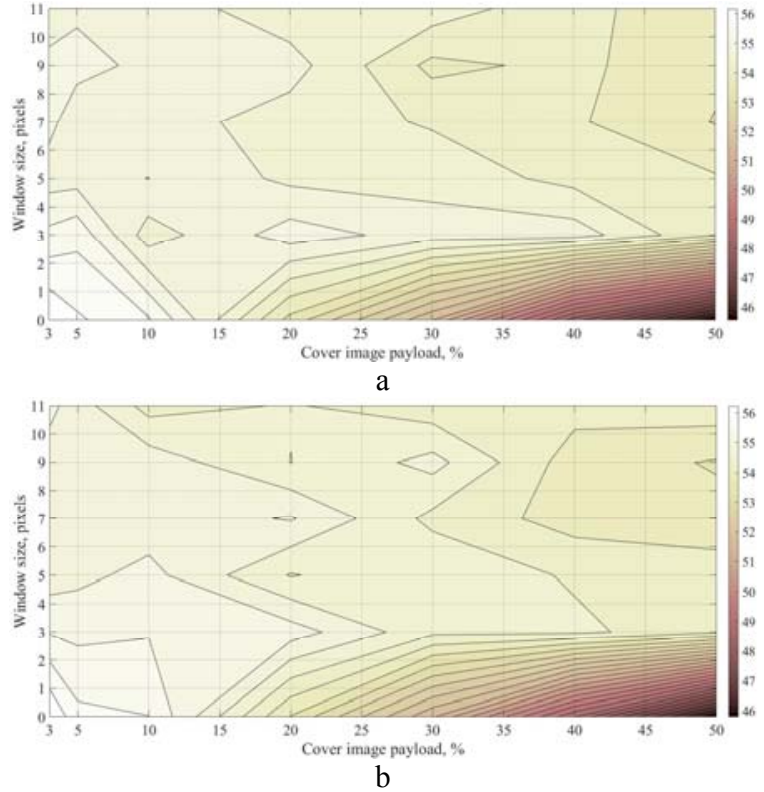

Figure 2 - Detection error $P_{e}$ as a function of the cover image payload and size $w_{s}$ of sliding windows for $F_{\text {noise }}$ features and Gaussian noising: $\mathrm{a}-\mathrm{MG}$ method; $\mathrm{b}-$ MiPOD method. The $P_{e}$ values for $F_{n \tilde{n}}$ features are represented by $w_{s}=0$ (pixels)

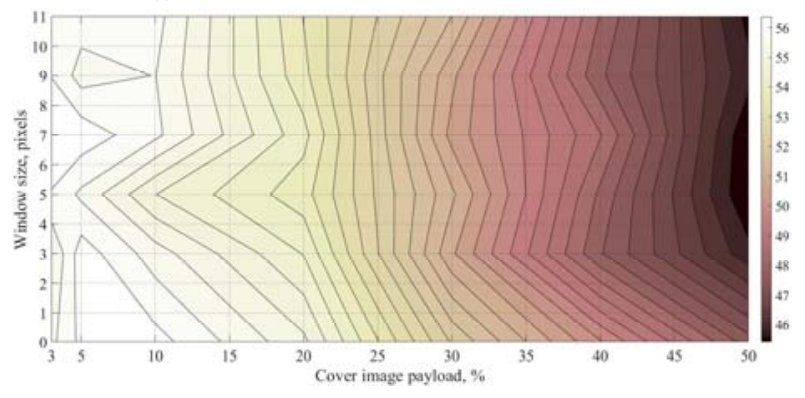

a

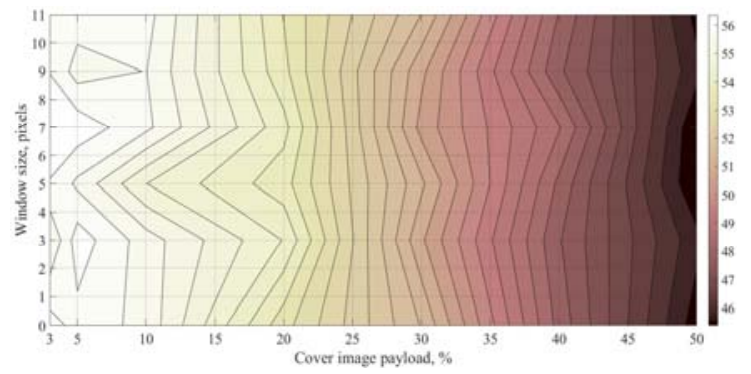

$\mathrm{b}$

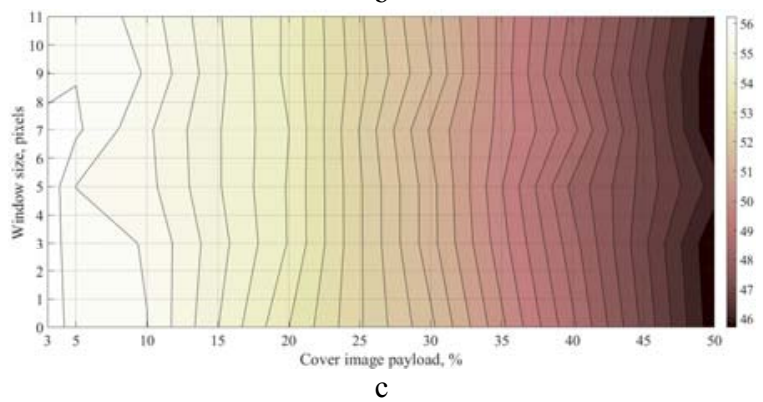

Figure 3 - Detection error $P_{e}$ as a function of the cover image payload and size $w_{s}$ of sliding windows for $F_{D F}$ features and Gaussian noising: a - HUGO method; b - MG method; c - MiPOD method. The $P_{e}$ values for $F_{n c}$ features are represented by $w_{s}=0$ (pixels)
Usage of linearly transformed features $F_{D F}$ (Fig. 3) leads to negligible decreasing of detection error for HUGO embedding method (about 2-3\%, Fig. 3) for medium and high values of $\Delta_{p}$ while preserving similar $P_{e}$ values for MG (Fig. 3b) and MiPOD (Fig. 3c) methods. On the other hand, applying of Cartesian calibrated features allows increasing detection error values (about $1-$ $2 \%)$ for all considered methods.

Applying of Cartesian calibrated features $F_{C C}$ (Fig. 4) allows achieving $P_{e}$ similar to transformed features $F_{D F}$ (Fig. 3). Therefore, usage of these features is impractical since significant decreasing of $P_{\mathrm{e}}$ was not achieved.
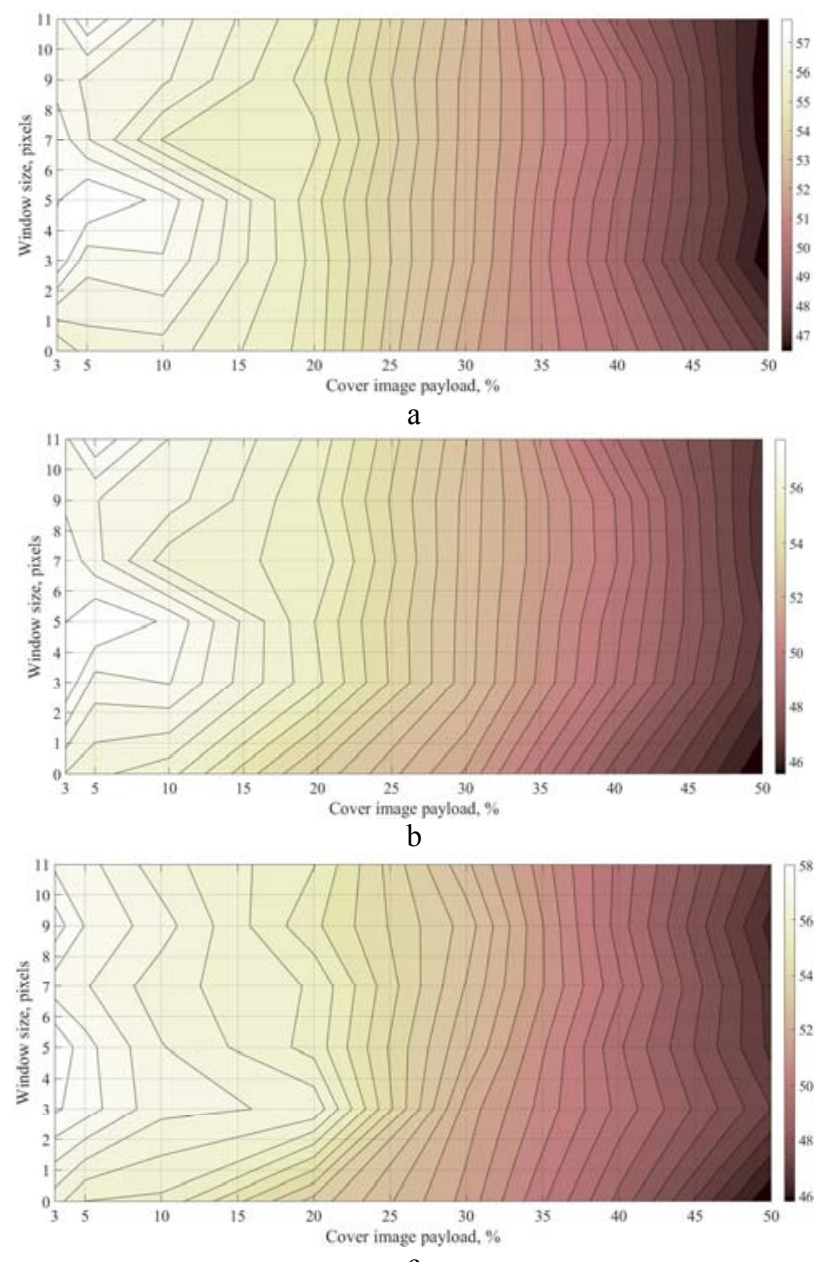

Figure 4 - Detection error $P_{e}$ as a function of the cover image payload and size $w_{s}$ of sliding windows for $F_{C C}$ features and

Gaussian noising: $\mathrm{a}-\mathrm{HUGO}$ method; $\mathrm{b}-\mathrm{MG}$ method; $\mathrm{c}-\mathrm{Mi}-$ POD method. The $P_{e}$ values for $F_{n c}$ features are represented by $w_{s}=0$ (pixels)

Detection error $P_{e}$ as a function of CI payload by Poisson noising is represented at Fig. 5-6. 


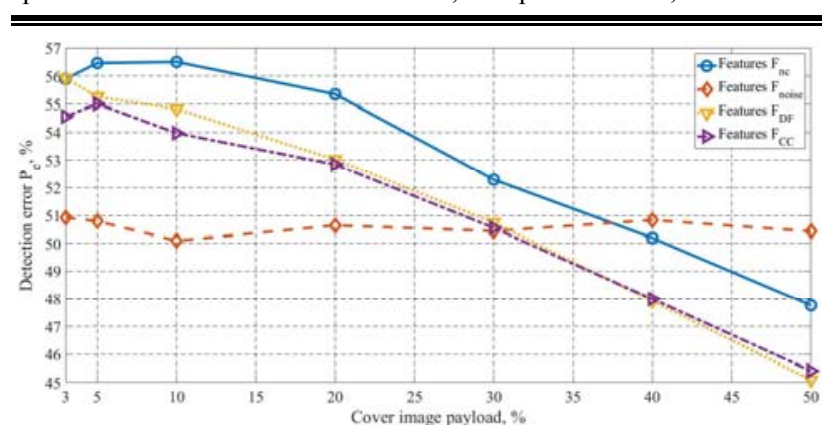

Figure 5 - Detection error $P_{e}$ as a function of the cover image payload by Poisson noising for HUGO method
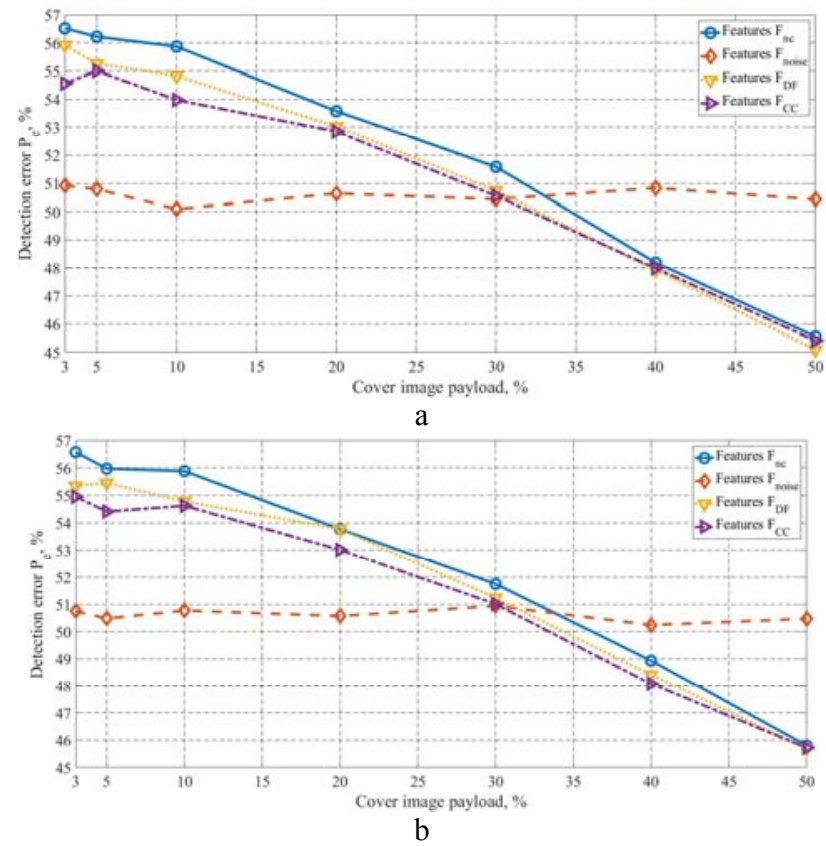

Figure 6 - Detection error $P_{e}$ as a function of the cover image payload by Poisson noising: a - MG method; $\mathrm{b}-$ MiPOD method

It can be seen from the Fig. 5-6 that proposed approach allows decreasing detection error up to $2 \%-3 \%$ for all considered AEM. The biggest impact on $P_{e}$ values was obtained for HUGO method (Fig. 5) while reducing of $P_{e}$ values for MG (Fig. 6a) and MiPOD (Fig. 6b) methods is negligible (up to $1 \%-1.5 \%$ ). Usage of features for noised images $F_{\text {noise }}$ leads to detection accuracy closed to random guessing.

\section{DISCUSSION}

Message embedding into $\mathrm{CI}$ can be represented as adding noises into high-textures areas of images $[1,2]$. Amplification of these changes can be achieved by additional noising of analyzed image, for example with noises related to image capturing process [4]. Obtained results for Gaussian noise (Fig. 1-4) showed that this approach is ineffective irrespective of used features (13)-(15). Applying of $F_{\text {noise }}$ features leads to catastrophic decrease of detection accuracy in whole range of CI payload (Fig. 1-2). This can be explained by substantial excess of introduced noise's energy in comparison to changes caused by mes- sage hiding. Therefore, added Gaussian noise totally eliminates CI influence caused by data embedding for all considered steganography methods.

Applying of linearly transformed features $F_{D F}$ (Fig. 3) allows improve detection accuracy a bit for HUGO embedding method (Fig. 1) - up to $2 \%-3 \%$ for medium and high payload of CI (more than 25\%). Changes of detection error $P_{e}$ are negligible and close to calculation errors for model-based MG (Fig. 2a) and MiPOD (Fig. 2b) methods. In this case, obtained amplification of CI alterations is insufficient for improving SD performance.

A similar situation exists for Cartesian calibrated features (Fig. 4) - image pre-noising leads to decreasing stegdetector accuracy a bit (about $1.5 \%-2 \%$ ) for considered EM. Therefore, usage of these features is impractical - stored information about initial and noised images do not allow distinguishing stego images from cover ones.

On the other hand, adding Poisson noises to DI allows reducing detection error $P_{e}$ even for low payload of CI (less than 10\%). Similar to previous case, this is achieved for Cartesian and linearly transformed features (Fig. 5-6). Noteworthy that revealed decreasing of detection error was obtained for all considered EM. This makes image preprocessing with Poisson noise valuable for steganalysis of natural digital images.

Obtained results for Gaussian and Poisson noises showed that introduced distortions to analyzed image effectively masking negligible changes caused by message hiding. This masking effect can be reduced only by usage of special types of features, namely Cartesian and linearly transformed ones. Therefore, further research of special types of images noising for accurate amplification of CI distortions caused by message hiding is needed.

\section{CONCLUSIONS}

The topical problem of reliable detection of stego images formed by advanced adaptive embedding methods was considered. The case of stego-to-cover ratio increasing by image pre-noising with Gaussian and Poisson noises was investigated.

The scientific novelty of obtained results is performance analysis of special types of digital image calibration, namely image noising. Proposed approach allows amplifying negligible changes of cover image caused by message hiding even in case of limited a priori information about used embedding method. This gives opportunity to improve statistical stegdetectors performance in case of analysis natural images that characterize high level of parameters variability.

The practical significance of obtained experimental results is dependencies of detection error on cover image payload for state-of-the-art adaptive embedding methods HUGO, MG and MiPOD. These results allow us to recommend Cartesian and linearly transformed features to be used for improving stegdetector performance by natural image pre-noising.

Prospects for further research are to investigate effectiveness of special types of images noising, such as 
fractal noises, for amplification of cover image cover image distortions caused message hiding.

\section{REFERENCES}

1. Fridrich J. Steganography in Digital Media: Principles, Algorithms, and Applications. Cambridge, Cambridge University Press, 2009, 437 p. ISBN 978-0-521-19019-0. DOI: 10.1017/CBO9781139192903.

2. Konachovych G., Progonov D., Puzyrenko O. Digital steganography processing and analysis of multimedia files. Kyiv, 'Tsentr uchbovoi literatury' publishing, 2018, 558 p. ISBN 978-617-673-741-4.

3. Kodovsky J., Fridrich J. Calibration revisited, Multimedia and security: $11^{\text {th }}$ ACM workshop, Princeton, 7-8 September, 2009: proceedings. Princeton: ACM, 2009, pp. 63-74. DOI: $10.1145 / 1597817.1597830$.

4. Progonov D. Analysis of the detection accuracy of stego images generated by adaptive embedding methods, with additional noise of images, Radioengineering Fields, Signals, Devices and Systems: International scientific and technical conference, Kyiv, 18-24 November, 2019: proceedings. Kyiv, Igor Sikorsky Kyiv Polytechnic Institute, 2019, pp. 225-227.

5. Yoan M., Bas P., Amaury L. Using multiple re-embeddings for quantitative steganalysis and image reliability estimation: TKK reports in information and computer science. Department of Information and Computer Science, Aalto University, 2010, 19 p. ISBN 978-952-60-3250-4.

6. Fridrich J., Kodovsky J. Rich models for steganalysis of digital images, IEEE Transactions on Information Forensics Security, 2012, Vol. 7, pp. 868-882. DOI: 10.1109/TIFS.2012.2190402.

7. Filler T., Fridrich J. Gibbs construction in steganography, IEEE Transactions on Information Forensics Security. 2010, Vol. 5, pp. 705-720. DOI: 10.1109/TIFS.2010.2077629.

8. Holub V., Fridrich J. Designing Steganographic Distortion Using Directional Filters, Information Fo-rensic and Security: IEEE International Workshop, Tenerife, 2-5 December, 2012: proceedings. Tenerife, IEEE, 2012. DOI: 10.1109/WIFS.2012.6412655.

9. Denemark T., Sedighi V., Holub V., Cogranne R., Fridrich J. Selection-Channel-Aware Rich Model for Steganalysis of Digital Images, Information Forensic and Security: IEEE International Workshop, Atlanta, 3-5 December, 2014: proceedings. IEEE, 2014. DOI: 10.1109/WIFS.2014.7084302.

10. Holub V., Fridrich J. Random Projections of Residuals for Digital Image Steganalysis, IEEE Transactions on Informa- tion Forensics Security, 2013, Vol. 8, pp. 1996-2013. DOI: 10.1109/TIFS.2013.2286682.

11. Boroumand M., Chen M., Fridrich J. Deep residual network for steganalysis of digital images, IEEE Transactions on Information Forensics Security, 2018, Vol. 14, pp. 11811193. DOI: 10.1109/TIFS.2018.2871749.

12. Progonov D., Lucenko V. Steganalysis of adaptive embedding methods by message re-embedding into stego images, Information Theories and Applications, 2020, Vol. 27, Issue 4, pp. 3-24

13. Gonzalez R., Woods R. Digital Image Processing. London, Pearson Press, 2017, 1192 p. ISBN 978-0133356724.

14. Filler T., Fridrich J. Design of adaptive steganographic schemes for digital images, Electronic Imaging, Media Watermarking, Security, and Forensics: The International Society for Optical Engineering, San Francisco, 24-26 January, 2011: proceedings. San Francisco, SPIE, 2011. DOI: $10.1117 / 12.872192$

15. Sedighi V., Fridrich J., Cogranne R. Content-adaptive pentary steganography using the multivariate generalized gaussian cover model, Electronic Imaging, Media Watermarking, Security, and Forensics: The International Society for Optical Engineering, San Francisco, 24-26 January, 2015: proceedings. San Francisco, SPIE, 2015. DOI: $10.1117 / 12.2080272$

16. Sedighi V., Cogranne R., Fridrich J. Content adaptive steganography by minimizing statistical detectability, IEEE Transactions on Information Forensics Security, 2015, Vol. 11, pp. 221-234. DOI: 10.1109/TIFS.2015.2486744.

17. Pevny T., Bas P., Fridrich J. Steganalysis by subtractive pixel adjacency matrix, IEEE Transactions on Information Forensics Security, 2010, Volume 5, pp. 215-224. DOI: 10.1109/TIFS.2010.2045842.

18. Cogranne R., Gilboulot Q., Bas P. The alaska steganalysis challenge: A first step towards steganalysis, Information Hiding and Multimedia Security: ACM workshop, Paris, 13 July, 2019: proceedings. Paris, ACM Press, 2019, pp. 125-137. DOI: 10.1145/3335203.3335726.

19. Kodovsky J., Fridrich J. Ensemble classifiers for steganalysis of digital media, IEEE Transactions on Information Forensics Security, 2012, Vol. 7, pp. 432-444. DOI: 10.1109/TIFS.2011.2175919.

20. Lim J. Two-Dimensional Signal and Image Processing. Upper Saddle River, Prentice Hall, 1989, 694 p. ISBN 9780139353222 .

Received 09.12.2020 Accepted 25.01.2021

УДК 004.056.54

\section{ВПЛИВ ПОПЕРЕДНЬОГО ЗАШУМЛЕННЯ ЦИФРОВИХ ЗОБРАЖЕНЬ НА ЕФЕКТИВНІСТЬ СТАТИСТИЧНИХ СТЕГОДЕТЕКТОРІВ}

Прогонов Д. О. - канд. техн. наук, доцент, доцент кафедри фізико-технічних засобів захисту інформації Національного технічного університету «Київський політехнічний інститут імені Ігоря Сікорського», Київ, Україна.

\section{АНОТАЦІЯ}

Актуальність. Розглянуто проблему захисту конфіденційної інформації під час передачі даних у системах зв'язку. Досліджено випадок виявлення стеганограм, сформованих згідно новітніх методів приховання повідомлень. Об'єктом дослідження є методи виявлення стеганограм з даними, вбудованими згідно адаптивними стеганографічними методами.

Метод. Запропоновано метод попередньої обробки зображень (калібрування) для підвищення співвідношення стегоконтейнер для сучасних адаптивних методів вбудовування HUGO, MG та MiPOD. Метод спрямований на посилення незначних змін зображення-контейнеру, обумовлених прихованням повідомлень. Підвищення досягається шляхом внесення до (C) Progonov D. O., 2021 DOI 10.15588/1607-3274-2021-1-18 
зображення додаткових шумів, що мають гаусовий або пуасоновий розподіл. Перший тип шуму пов'язаний з тепловим шумом, який впливає на матрицю фотоелементів під час формування зображення. Другий тип шуму пов'язаний зі стохастичною природою процесу випромінювання електронів фотонами, що потрапляють на елементи матриці фотоелементів. Дисперсія теплових шумів оцінювалася з використанням двовимірного фільтра Вінера при варіації розміру ковзного вікна. Параметри розподілу Пуассона було визначено з використанням ковзного вікна розміром $5 \cdot 5$ пікселів.

Результати. Побудовано залежності помилки виявлення від ступеня заповнення зображення-контейнеру стегоданими для методів вбудовування HUGO, MG та MiPOD. Результати представлені для випадку внесення до зображень шуму з гаусовим та пуасоновим розподілами, а також застосуванні різних методів попередньої обробки характеристик.

Висновки. Проведені експерименти підтвердили ефективність запропонованого підходу до калібрування зображень 3 використанням пуасонівських шумів. Отримані результати дозволяють рекомендувати використання декартових і лінійно трансформованих ознак стеганограм для підвищення точності роботи стегодетектору. Перспективи подальших досліджень можуть включати вивчення ефективності застосування спеціальних типів шумів, зокрема фрактальних шумів, $з$ метою підвищення співвідношення стегодані-контейнер для сучасних стеганографічних методів.

КЛЮЧОВІ СЛОВА: стегоаналіз цифрових зображень, адаптивні методи приховання, Гаусовий шум, Пуасоновий шум.

УДК 004.056.54

\section{ВЛИЯНИЕ ПРЕДВАРИТЕЛЬНОГО ЗАШУМЛЕНИЯ ЦИФРОВЫХ ИЗОБРАЖЕНИЙ НА ЭФФЕКТИВНОСТЬ СТАТИСТИЧЕСКИХ СТЕГОДЕТЕКТОРОВ}

Прогонов Д. О. - канд. техн. наук, доцент, доцент кафедры физико-технических средств защиты информации Национального технического университета «Киевский политехнический институт имени Игоря Сикорского», Киев, Украина.

\section{АННОТАЦИЯ}

Актуальность. Рассмотрена проблема защиты конфиденциальной информации при передаче данных в системах связи. Исследован случай выявления стеганограмм, сформированных согласно современным методам скрытия информации. Объектом исследования являются методы выявления стеганограмм с данными, встроенными согласно адаптивным стеганографическим методам.

Метод. Предложен метод предварительной обработки (калибровки) изображений для повышения соотношения стегоданные-контейнер для современных адаптивных стеганографических методов HUGO, MG и MiPOD. Метод направлен на усиление незначительных искажений изображения-контейнера, обусловленных встраиванием данных. Усиление искажений достигается путем внесения в изображение дополнительных шумов, имеющих гауссовый и пуассоновый распределения. Первый тип шумов связан с тепловым шумом, который влияет на датчик изображения на основе прибора с зарядовой связью (ПЗС) во время формирования изображения. Второй тип шума связан с дробовым шумом, который возникает в результате случайного процесса испускания электронов фотонами, попадающими на элементы ПЗС. Дисперсия тепловых шумов оценивалась с помощью двумерного фильтра Винера при вариации размеров скользящего окна. Параметры распределения Пуассона оценивалось с помощью скользящего окна размером $5 \cdot 5$ пикселей.

Результаты. Построены зависимости ошибки обнаружения от степени заполнения изображения-контейнера стегоданными для методов встраивания HUGO, MG и MiPOD. Результаты представлены для случая внесения в изображения шума с гауссовым и пуасоновим делениями, а также применении различных методов предварительной обработки характеристик.

Выводы. Проведенные эксперименты подтвердили эффективность предложенного подхода к калибровке изображений с использованием пуассоновских шумов. Полученные результаты позволяют рекомендовать использование декартовых и линейно преобразованных признаков стеганограмм для повышения точности работы стегодетектора. Перспективы дальнейших исследований могут включать изучение эффективности специальных типов шумов, таких как фрактальные шумы, с целью повышения соотношения стегоданные-контейнер для современных стеганографических методов.

КЛЮЧЕВЫЕ СЛОВА: стегоанализ цифровых изображений, адаптивные методы встраивания, Гауссовый шум, Пуассоновский шум.

\section{ЛІТЕРАТУРА / ЛИТЕРАТУРА}

1. Fridrich J. Steganography in Digital Media: Principles, Algorithms, and Applications / J. Fridrich. - Cambridge: Cambridge University Press, 2009. - 437 p. - ISBN 978-0521-19019-0. - DOI: 10.1017/CBO9781139192903.

2. Конахович Г. Ф. Комп’ютерна стеганографічна обробка й аналіз мультимедійних даних / Г. Ф. Конахович, Д. О. Прогонов, О. Ю. Пузиренко. - Київ : «Центр учбової літератури», 2018. - 558 с. - ISBN 978-617-673$741-4$

3. Kodovsky J. Calibration revisited / J. Kodovsky, J. Fridrich // Multimedia and security: $11^{\text {th }}$ ACM workshop, Princeton, 7-8 September, 2009 : proceedings. - Princeton : ACM, 2009. - P. 63-74. - DOI: 10.1145/1597817.1597830.

4. Прогонов Д. О. Аналіз точності виявлення стеганограм, сформованих адаптивними методами, при додатковому зашумленні зображень-контейнерів / Д. О. Прогонов //
Радіотехнічні поля, сигнали, апарати та системи: міжнародна науково-технічна конференція, Київ, 18-24 листопада, 2019 : матеріали. - Київ : КПІ ім. Ігоря Сікорського, 2019. - С. 225-227.

5. Yoan M. Using multiple re-embeddings for quantitative steganalysis and image reliability estimation: TKK reports in information and computer science / M. Yoan, P. Bas, L. Amaury. - Department of Information and Computer Science, Aalto University, 2010. - 19 p. - ISBN 978-952-603250-4.

6. Fridrich J. Rich models for steganalysis of digital images / J. Fridrich, J. Kodovsky // IEEE Transactions on Information Forensics Security. - 2012. - Vol. 7. - P. 868-882. - DOI: 10.1109/TIFS.2012.2190402.

7. Filler T. Gibbs construction in steganography / T. Filler, J. Fridrich // IEEE Transactions on Information Forensics 
Security. - 2010. - Vol. 5. - P. 705-720. - DOI: 10.1109/TIFS.2010.2077629.

8. Holub V. Designing Steganographic Distortion Using Directional Filters / V. Holub, J. Fridrich // Information Fo-rensic and Security: IEEE International Workshop, Tenerife, 2-5 December, 2012: proceedings. - Tenerife : IEEE, 2012. DOI: 10.1109/WIFS.2012.6412655.

9. Selection-Channel-Aware Rich Model for Steganalysis of Digital Images / [T. Denemark, V. Sedighi, V. Holub et all] // Information Forensic and Security: IEEE International Workshop, Atlanta, 3-5 December, 2014: proceedings. IEEE, 2014. - DOI: 10.1109/WIFS.2014.7084302.

10. Holub V. Random Projections of Residuals for Digital Image Steganalysis / V. Holub, J. Fridrich // IEEE Transactions on Information Forensics Security. - 2013. - Vol. 8. - P. 1996-2013. - DOI: 10.1109/TIFS.2013.2286682.

11. Boroumand M. Deep residual network for steganalysis of digital images / M. Boroumand, M. Chen, J. Fridrich // IEEE Transactions on Information Forensics Security. - 2018. Vol. 14. - $\quad$ P. 1181-1193. - DOI: 10.1109/TIFS.2018.2871749.

12. Progonov D. Steganalysis of adaptive embedding methods by message re-embedding into stego images / D. Progonov, V. Lucenko // Information Theories and Applications 2020. - Vol. 27, Issue 4. - P. 3-24

13. Gonzalez R. Digital Image Processing / R. Gonzalez, R. Woods. - London : Pearson Press, 2017. - 1192 p. ISBN 978-0133356724.

14. Filler $T$. Design of adaptive steganographic schemes for digital images / T. Filler, J. Fridrich // Electronic Imaging, Media Watermarking, Security, and Forensics: The International Society for Optical Engineering, San Francisco, 24
26 January, 2011: proceedings. - San Francisco : SPIE, 2011. - DOI: $10.1117 / 12.872192$.

15. Sedighi V. Content-adaptive pentary steganography using the multivariate generalized gaussian cover model / V. Sedighi, J. Fridrich, R. Cogranne // Electronic Imaging, Media Watermarking, Security, and Forensics: The International Society for Optical Engineering, San Francisco, 2426 January, 2015: proceedings. - San Francisco: SPIE, 2015. - DOI: 10.1117/12.2080272.

16. Sedighi V. Content adaptive steganography by minimizing statistical detectability / V. Sedighi, R. Cogranne, J. Fridrich // IEEE Transactions on Information Forensics Security. 2015. - Vol. 11. - P. 221-234. DOI: 10.1109/TIFS.2015.2486744.

17. Pevny T. Steganalysis by subtractive pixel adjacency matrix / T. Pevny, P. Bas, J. Fridrich // IEEE Transactions on Information Forensics Security. - 2010. - Vol. 5. - P. 215 224. - DOI: 10.1109/TIFS.2010.2045842.

18. Cogranne R. The alaska steganalysis challenge: A first step towards steganalysis / R. Cogranne, Q. Gilboulot, P. Bas // Information Hiding and Multimedia Security: ACM workshop, Paris, 1-3 July, 2019: proceedings. - Paris: ACM Press, 2019. - P. 125-137. - DOI: 10.1145/3335203.3335726.

19. Kodovsky J. Ensemble classifiers for steganalysis of digital media / J. Kodovsky, J. Fridrich // IEEE Transactions on Information Forensics Security. - 2012. - Vol. 7. - P. 432444. - DOI: 10.1109/TIFS.2011.2175919.

20. Lim J. Two-Dimensional Signal and Image Processing / J. Lim. - Upper Saddle River : Prentice Hall, 1989. 694 p. - ISBN 978-0139353222. 